\title{
Chemical and Nutritional Evaluation of Biscuit Processed from Cassava and Pigeon Pea Flour
}

Ashaye $\mathrm{OA}^{1 *}$, Olanipekun $\mathrm{OT}^{1}$ and Ojo $\mathbf{S O}^{2}$

${ }^{1}$ Institute of Agricultural Research and Training P.M.B 5029, Moor-Plantation Ibadan, Nigeria

${ }^{2}$ Federal College of Agriculture, Ibadan, Nigeria

\begin{abstract}
Cassava is an important crop in the tropics. The use of cassava flour and pigeon pea flour in the manufacture of biscuit is uncommon. The chemical and nutritional evaluation of biscuit processed from cassava and pigeon pea flour was investigated. Commercial and cassava based biscuit were evaluated for chemical and nutritive properties. Sensory evaluation was done by a ten member panel randomly selected from male and female adults. One hundred percent cassava biscuit was significantly higher than other biscuit samples in Hydro-cyanide $(\mathrm{HCN})$ at $\mathrm{P}<0.05$. The crude protein and ash content of $30 \%$ cassava pigeon pea biscuit was significantly higher than other biscuit samples. Commercial biscuit was higher in crude fat (13.54\%), crude fibre $(0.85 \%)$ and moisture content $(4.8 \%)$. Sensory evaluation showed that commercial biscuit, $30 \%$ cassava-pigeon pea biscuit and $100 \%$ cassava biscuit were not significantly different from each other in colour. Higher scores were given to $30 \%$ cassava-pigeon biscuit. The taste, texture, flavour and general acceptability of $100 \%$ cassava biscuit and commercial biscuit were not significantly different from each other. Generally, acceptable biscuit was processed from $100 \%$ cassava flour and $30 \%$ cassava pigeon flour. Thirty percent cassava pigeon biscuit gave better nutrient attributes and sensory scores than commercial biscuit.
\end{abstract}

Keywords: Biscuit; Cassava pigeon pea; Chemical; Nutritional; Sensory

\section{Introduction}

Cassava is sometimes classified as a crop for developing countries and for consumption only by rural people, whereas the large crop of cassava grown annually in the tropics is actually consumed in all its forms at nearly all income levels [1]. It is a very important crop in the tropics where an estimate of a billion people depends on it as a major staple crop. It is an important crop in the farming system because it can be intercropped with many other crops, and yield well in poor soils. Cassava is the fourth most important staple crop in the world after rice, wheat and maize [2]. It is a chief source of edible carbohydrate that could be processed into different forms of human foods, e.g., fufu, eba, gari, lafun, pupuru, abacha, etc. The cultivation of cassava requires minimal input but the processing is laborious and time consuming. Cassava contains $1 \%$ protein, $97 \%$ starch, $1 \%$ fibre with traces of fat and other minerals [2].

Pigeon pea (Cajanus cajan (L) Mill sp.) belongs to the family of Cajanicae. It is the only domesticated species well distinguished by the presence of vascular glands on the leaves, calyx and pods [3]. Pigeon pea seed is one of the tropical legume seeds which have been highly favourable because of its rich protein composition, energy and mineral content and widespread distribution in the tropics. However, its nutritive value is masked by the occurrence of anti-nutritional factors. Some of the anti-nutritional factors are known to have negative effect on the haematological parameters, but can easily be removed through processing by heat [3]. Biscuits are an ideal source of food as they possess the following attributes: they are highly palatable and acceptable, they have long storage and good sources of energy, they provide a good source of energy and can easily be modified to suit specific nutritional needs of any target population, and they can be produced in convenient sizes and different forms. Biscuit is therefore one of the popular food sources in any emergency feeding programme [4]. There is limited information about the production of biscuit from cassava and pigeon pea flour. Hence this work aims at evaluating the nutritional properties and consumer acceptability of biscuit made from cassava and pigeon pea flour.

\section{Materials and Methods}

\section{Raw materials}

The cassava tubers were procured from the Federal College of Agriculture Farm in Ibadan, while the pigeon pea was purchased from Apata Market in Ibadan, Oyo state Nigeria. The variety of cassava tubers was the sweet variety (TMS 20001 Variety) and other ingredients such as baking ingredients were also purchased from Apata Market.

\section{Preparation of cassava and pigeon pea flour}

The cassava tubers were harvested fresh, peeled manually, washed and grated. The grated mash was packed into perforated sack and pressed using the hydraulic press to drain out water after which it was sun-dried and dry-milled. Pigeon pea was par-boiled in hot water for 5 minutes, peeled, sun-dried and ground using electric blender.

\section{Preparation of cassava based biscuits}

Cassava based biscuits were processed from $100 \%$ cassava flour, $10 \%, 20 \%, 30 \%$ cassava/pigeon pea flour using commercial biscuit as control. Biscuit from cassava and cassava pigeon flour were processed by mixing about $100 \mathrm{gm}$ of the flour with the following ingredients 0.15 $\mathrm{g}$ of salt, $15 \mathrm{~g}$ of sugar, $10 \mathrm{~g}$ of fat, $0.25 \mathrm{~g}$ of baking powder, $0.25 \mathrm{~g}$ of vanilla flavor. About $100 \mathrm{ml}$ of water was gradually added while mixing together for 6 minutes to obtain slightly textured dough. The dough was kneaded on a flat rolling board and was manually rolled into sheet and

*Corresonding author: Ashaye OA, Institute of Agricultural Research and Training P.M.B 5029, Moor-Plantation Ibadan, Nigeria, Tel: +2348023253829; Email: kayodeashaye@yahoo.com

Received October 15, 2015; Accepted October 15, 2015; Published November 15,2015

Citation: Ashaye OA, Olanipekun OT, Ojo SO (2015) Chemical and Nutritional Evaluation of Biscuit Processed from Cassava and Pigeon Pea Flour. J Food Process Technol 6: 521. doi:10.4172/2157-7110.1000521

Copyright: (c) 2015 Ashaye OA, et al. This is an open-access article distributed under the terms of the Creative Commons Attribution License, which permits unrestricted use, distribution, and reproduction in any medium, provided the original author and source are credited. 
cut into shapes using a suitably shaped tin. The cut pieces of dough were placed into a greased oven tray, baked at $180^{\circ} \mathrm{C}$ for 20 minutes using the modified method of Eneche [5] (Figure 1).

\section{Determination of Proximate Composition of biscuit samples}

The biscuit samples were analysed for moisture, dry matter, crude protein, crude fat, crude fibre and ash using the standard methods of AOAC [6].

\section{Dry matter and moisture determination}

The sample $(2 \mathrm{~g})$ was weighed into a previously weighed crucible. The crucible plus sample taken was then transferred into the oven set at $100^{\circ} \mathrm{C}$ to dry to a constant weight for 24 hours overnight. At the end of the 24 hours, the crucible plus sample was removed from the oven and transferred to desiccator, cooled for ten minutes and weighed [6].

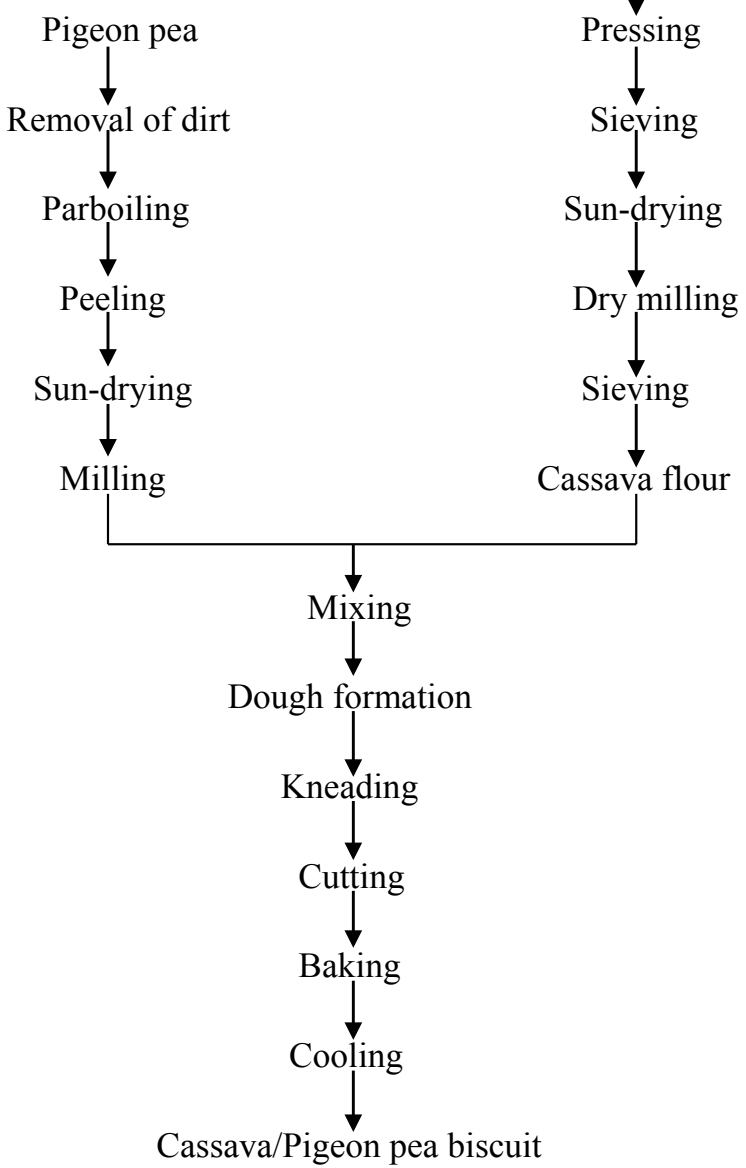

Figure 1: Flow Chart of the process of making cassava/pigeon pea biscuit.
If the weight of empty crucible is $\mathrm{W}_{0}$

Weight of crucible plus sample is $\mathrm{W}_{1}$

Weight of crucible plus oven dried sample $\mathrm{W}_{3}$

$$
\begin{aligned}
& (\% \mathrm{DM}) \% \text { Dry Matter }=\frac{\mathrm{W}_{3}-\mathrm{W}_{0}}{\mathrm{~W}_{1}-\mathrm{W}_{0}} \times 100 \\
& \% \text { Moisture }=\frac{\mathrm{W}_{1}-\mathrm{W}_{3}}{\mathrm{~W}_{1}-\mathrm{W}_{0}} \times 100
\end{aligned}
$$

\section{Determination of Ash}

The sample (2g) was weighed into a porcelain crucible. This was transferred into the muffle furnace set at $550^{\circ} \mathrm{C}$ and left for about 4 hours. About this time it had turned to white ash. The crucible and its content were cooled to about $100^{\circ} \mathrm{C}$ in air, then room temperature in a desiccator and weighed [6].

The percentage ash was calculated from the formula below:

$\%$ Ash content $=\frac{\text { Weight of ash }}{\text { Original weight of sample }} \times 100$

\section{Determination of crude protein}

The micro-Kjeldahl method for protein determination is employed for protein determination. This is based on three principles:

$$
\begin{aligned}
& \text { Digestion: } \mathrm{RNH}_{2}+2 \mathrm{H}_{2} \mathrm{SO}_{4} \rightarrow\left(\mathrm{NH}_{4}\right)_{2}+\mathrm{SO}_{4}+\mathrm{CO}_{2}+\mathrm{H}_{2} \mathrm{O} \\
& \text { Distillation: }\left(\mathrm{NH}_{4}\right)_{2} \mathrm{SO}_{4}+2 \mathrm{NaOH} \rightarrow \mathrm{NH}_{3}+\mathrm{H}_{2} \mathrm{O}+\mathrm{Na}_{2} \mathrm{SO}_{4} \\
& \text { Absorption: } 3 \mathrm{NH}_{3}+\mathrm{H}_{3} \mathrm{BO}_{3} \rightarrow\left(\mathrm{NH}_{4}\right)_{3} \mathrm{BO}_{3} \\
& \text { Titration: }\left(\mathrm{NH}_{4}\right)_{3} \mathrm{BO}_{3}+\mathrm{HCl} \rightarrow \mathrm{H}_{3} \mathrm{BO}_{3}+3 \mathrm{NH}_{4} \mathrm{Cl}
\end{aligned}
$$

\section{Procedure}

The bread sample $(0.5 \mathrm{~g})$ was weighed into the micro-Kjeldahl flask. To this were added 1 Kjeldahl catalyst tablet and $10 \mathrm{ml}$ of conc. $\mathrm{H}_{2} \mathrm{SO}_{4}$. These were set in the appropriate hole of the digestion block heaters in a fume cupboard. The digestion was left on for 4 hours after which a clear colourless solution was left in the tube. The digest was carefully transferred into $100 \mathrm{ml}$ volumetric flask, thoroughly rinsing the digestion tube with distilled water and the volume of the flask made up to the mark with distilled water. $5 \mathrm{ml}$ portion of the digest was then pipetted to Kjeldahl apparatus and $5 \mathrm{ml}$ of $40 \%\left({ }^{\mathrm{w}} / \mathrm{v}\right) \mathrm{NaOH}$ added.

The mixture was then steam distilled and the liberated ammonia collected into a $50 \mathrm{ml}$ conical flask containing $10 \mathrm{ml}$ of $2 \%$ boric acid plus mixed indicator solution. The green colour lsolution was then titrated against $0.01 \mathrm{NHCl}$ solution. At the end point, the green colour turns to wine colour, which indicates that, all the nitrogen trapped as ammonium borate have been removed as ammonium chloride. The percentage nitrogen was calculated by using the formula:

$\% \mathrm{~N}=$ Titre value $\mathrm{x}$ atomic mass of nitrogen $\mathrm{x}$ normality of $\mathrm{HCl}$ used $\mathrm{x} 4$

The crude protein is determined by multiplying percentage nitrogen by a constant factor of 6.25 [6].

\section{Crude fat determination}

The dried sample (1g) was weighed into fat free extraction thimble and plug lightly with cotton wool. The thimble was placed in the extractor and fitted up with reflux condenser and a $250 \mathrm{ml}$ soxhlet flask which has been previously dried in the oven, cooled in the dessicator and weighed. The soxhlet flask is then filled to $3 / 4$ of it volume with 
petroleum either (B.Pt. $40-60^{\circ} \mathrm{C}$ ) and the soxhlet flask extractor plus condenser set was placed on the heater. The heater was put on for six hours with constant running water from the tap for condensation of ether vapour. The set is constantly watched for ether leaks and the heat sources is adjusted appropriately for the either to bril gently. The ether is left to siphon over several times at least 10-12 times until it is short of siphoning. It is after this is noticed that any ether content of the extractor is carefully drained into the ether stock bottle. The thimble-containing sample is then removed and dried on a clock glass on the bench top. The extractor flask with condenser is replaced and the distillation continues until the flask is practically dried. The flask which now contains the fat or oil is detached, its exterior cleaned and dried to a constant weight in the oven [6]. If the initial weight of dry soxhlet flask is $\mathrm{W}_{\mathrm{o}}$ and the final weight of oven dried flask + oil/fat is $\mathrm{W}_{1}$, percentage fat/oil is obtained by the formula:

$$
\text { percentage of fat } / \text { oil }=\frac{\mathrm{W}_{1}-\mathrm{W}_{\mathrm{o}}}{\text { Weight of sample taken }} \times 100
$$

\section{Crude fibre determination}

The sample (2g) was accurately weighed into the fibre flask and 100 $\mathrm{ml}$ of $0.25 \mathrm{~N} \mathrm{H}_{2} \mathrm{SO}_{4}$ added. The mixture was heated under reflux for 1 hour with the heating mantle. The hot mixture was filtered through a fibre sieve cloth. The filtrate obtained was thrown off and the residue was returned to the fibre flask to which $100 \mathrm{ml}$ of $(0.31 \mathrm{~N} \mathrm{NaOH})$ was added and heated under reflex for another 1 hour.

The mixture was filtered through a fibre sieve cloth and $10 \mathrm{ml}$ of acetone added to dissolve any organic constituent. The residue was washed with about $50 \mathrm{ml}$ hot water twice on the sieve cloth before it was finally transferred into the crucible. The crucible and the residue were oven-dried at $105^{\circ} \mathrm{C}$ overnight to drive off moisture. The ovendried crucible containing the residue was cooled in a desiccator and later weighed to obtain the weight $\mathrm{W}_{1}$. The crucible with weight $\mathrm{W}_{1}$ was transferred to the muffle furnace for ashing at $550^{\circ} \mathrm{C}$ for 4 hours. The crucible containing white or grey ash (free of carbonaceous material) was cooled in the desiccator and weighed to obtain $\mathrm{W}_{2}$. The difference $\mathrm{W}_{1}-\mathrm{W}_{2}$ gives the weight of fibre [6]. The percentage fibre was obtained by the formula:

$$
\% \text { Fibre }=\frac{\mathrm{W}_{1}-\mathrm{W}_{2}}{\text { Weight of sample }} \times 100
$$

\section{HCN determination}

$0.1 \mathrm{gm}$ of the biscuit samples were weighed into a flat bottom plastic bottle with a screw cap lid. $0.5 \mathrm{ml}$ of $0.1 \mathrm{~m}$ phosphate buffer at $\mathrm{pH} 6$ was added in a pipette. A yellow picrate paper attached to a plastic strip immediately in the flat bottom plastic bottle containing samples and buffer, making sure that the picrate paper does not touch the liquid in the bottle. The bottle was immediately closed with the screw capped lid. A blank was also prepared as above into another screw capped bottle.

Linamarin standard stock solutions were also prepared using $10 \mathrm{mg}$ linamarin in $10 \mathrm{ml}, 0.1 \mathrm{ml}$ phosphate buffer at $\mathrm{pH}$. This was diluted to give concentrations of $25 \mathrm{ppm}$ to $100 \mathrm{ppm}$ (ie $25,50,75,100$ ). This was used to standardize and calibrate the spectrophotometer. Linamarin paper of 50ppm concentration was treated as sample above and put in a separate screw capped plastic bottle containing phosphate buffer and linamarase enzyme and the bottle was closed immediately.

All bottles containing samples, blank and linamarine standard paper were allowed to stand for 16-24 hours at room temperature. At the end of 16-24 hours, the bottles were opened, plastic baking sheet if the picrate paper were removed and placed in a test tube. $5 \mathrm{ml}$ of distilled water was pipette into the test tube containing the picrate paper and was allowed to stand for 30 minutes with occasional gentle stirring. The absorbance of all solutions in the test tube including linamarin standard solution were measured against blank on spectronic 20 spectrophotometer at a wavelength of $510 \mathrm{~mm}$ [7].

The total cyanide content $(\mathrm{ppm})$ or $\mathrm{mg} / \mathrm{kg}=396 \times$ absorbance.

$$
\% \text { Total cyanide content }=\frac{\text { ppm cyanide }}{10,000}
$$

\section{Results and Discussion}

\section{Chemical composition of biscuit samples}

Table 1 describes the chemical composition of biscuit samples. The hydrocyanic acid content $(\mathrm{HCN})$ of biscuit processed solely from cassava flour was significantly higher than other biscuit samples. Although level of HCN $\left(9.70 \mathrm{mgkg}^{-1}\right)$ is within the safe level [8]. It was also observed that there was a consistent drop in the level of $\mathrm{HCN}$ in cassava-pigeon pea biscuit with increase in fortification levels. This trend is as a result of increased presence of pigeon pea flour due to substitution. Pigeon pea flour processed from parboiling is known to be deficient in HCN due to the fact that $\mathrm{HCN}$ is heat labile [9]. HCN of commercial biscuit and 30\% cassava-pigeon pea biscuit are not significantly different from each other at $\mathrm{P}<0.05$. The crude protein content of $100 \%$ cassava biscuit was significantly lower than other biscuit samples with $30 \%$ cassavapigeon pea biscuit having a crude protein content of (7.97\%). Cassava flour is known to be poor in protein; there was also a gradual increase in the level of \% crude protein in cassava-pigeon pea biscuit with increase in fortification. It agreed with the findings of Ubbor and Akobundu [4] who asserted that protein content of cassava based composite flours could be elevated through the incorporation of legume flours. The ash content of $30 \%$ cassava-pigeon pea biscuit was higher than other biscuit samples at $\mathrm{P}<0.05$. Ash content also increased with increase in level of fortification. Pigeon pea flour is known to be rich in minerals. Crude fat which is responsible for maintenance of human health and brain development [10] was significantly greater in commercial biscuit (control) than other samples. This could be due to greater content of animal fat used in the preparation of the commercial biscuit. It was also evident that percentage crude fat increased with increasing level of fortification. The crude fibre and moisture content of commercial biscuit (control) was higher than other biscuit samples at $(\mathrm{P}<0.05)$. Gradual increase in crude fibre content of cassava-pigeon pea biscuit

\begin{tabular}{|c|c|c|c|c|c|c|c|}
\hline & HCN $\left(\mathbf{m g k g}^{-1}\right)$ & Crude Protein (\%) & Ash (\%) & Crude Fat (\%) & Crude Fibre (\%) & Moisture Content (\%) & Dry Matter (\%) \\
\hline 100\% Cassava Biscuit & $9.70^{\mathrm{a}}$ & $6.57^{\mathrm{d}}$ & $1.53^{c}$ & $0.11^{c}$ & $0.19^{d}$ & $3.00^{\mathrm{b}}$ & $97.00^{\mathrm{a}}$ \\
\hline $10 \%$ Cassava/pigeon pea biscuit & $8.32^{\mathrm{b}}$ & $6.92^{\mathrm{cd}}$ & $1.45^{\mathrm{d}}$ & $0.14^{c}$ & $0.14^{\mathrm{c}}$ & $3.50^{\mathrm{b}}$ & $96.50^{\mathrm{a}}$ \\
\hline $20 \%$ Cassava/pigeon pea biscuit & $2.58^{c}$ & $7.53^{\mathrm{ab}}$ & $1.60^{\mathrm{b}}$ & $0.24^{b}$ & $0.24^{\mathrm{c}}$ & $3.00^{\mathrm{b}}$ & $97.00^{\mathrm{a}}$ \\
\hline $30 \%$ Cassava/pigeon pea biscuit & $0.06^{d}$ & $7.97^{\mathrm{a}}$ & $1.67^{\mathrm{a}}$ & $0.33^{b}$ & $0.47^{\mathrm{b}}$ & $3.00^{\mathrm{b}}$ & $97.00^{\mathrm{a}}$ \\
\hline Commercial biscuit (Control) & $0.02^{d}$ & $7.09^{\mathrm{bc}}$ & $1.16^{c}$ & $13.54^{\mathrm{a}}$ & $0.85^{\mathrm{a}}$ & $4.81^{\mathrm{a}}$ & $95.19^{b}$ \\
\hline
\end{tabular}
with greater measure of pigeon pea flour was also observed. There was however no significant difference in the moisture content percentage in

(a-d)Means along the same column followed by the same letter are not significantly different from each other $(P<0.05)$

Table 1: Chemical composition of biscuit samples. 
Citation: Ashaye OA, Olanipekun OT, Ojo SO (2015) Chemical and Nutritional Evaluation of Biscuit Processed from Cassava and Pigeon Pea Flour. J Food Process Technol 6: 521. doi:10.4172/2157-7110.1000521

Page 4 of 4

\begin{tabular}{|l|c|c|c|c|}
\hline & Colour & Taste & Texture & Flavour \\
\hline $\mathbf{1 0 0} \%$ Cassava Biscuit & $8.10^{\mathrm{a}}$ & $8.20^{\mathrm{a}}$ & $7.40^{\mathrm{a}}$ & $7.40^{\mathrm{a}}$ \\
\hline $\mathbf{1 0} \%$ Cassava/pigeon pea biscuit & $6.00^{\mathrm{b}}$ & $4.40^{\mathrm{c}}$ & $5.20^{\mathrm{c}}$ & $4.80^{\mathrm{c}}$ \\
\hline $\mathbf{2 0} \%$ Cassava/pigeon pea biscuit & $6.00^{\mathrm{b}}$ & $6.60^{\mathrm{b}}$ & $5.50^{\mathrm{bc}}$ & $6.00^{\mathrm{bc}}$ \\
\hline $\mathbf{3 0} \%$ Cassava/pigeon pea biscuit & $8.00^{\mathrm{a}}$ & $7.40^{\mathrm{ab}}$ & $6.80^{\mathrm{ab}}$ & $6.80^{\mathrm{ab}}$ \\
\hline Commercial biscuit (Control) & $8.10^{\mathrm{a}}$ & $8.10^{\mathrm{a}}$ & $7.20^{\mathrm{a}}$ & $8.10^{\mathrm{a}}$ \\
\hline
\end{tabular}

${ }^{(a-c)}$ Means along the same column followed by the same letter are not significantly different from each other $(P<0.05)$.

Table 2: Sensory evaluation of biscuit samples

cassava-based biscuits, which was also observed with respect to their dry matter content. The values observed with regards to their moisture content and crude fibre were within the acceptable levels [11-13].

\section{Sensory evaluation of the biscuit samples}

Table 2 shows the sensory evaluation of the biscuit samples. There was no significant difference in the colour, taste, texture and general acceptability of 100 percent cassava biscuit and commercial biscuit. This implies this implies that acceptable biscuits can be processed from $100 \%$ percent cassava flour. However, 30 percent cassava-pigeon pea biscuit was high in colour, taste, texture, flavor and general acceptability. It is noteworthy that 20 and 30 percent cassava-pigeon pea biscuit were acceptable. This result agreed with the findings of Taiwo [14] who observed that biscuits processed from cassava and legume flours come out with the good sensory attributes.

\section{Conclusion}

The result of this research reveals that acceptable biscuits can be processed from $100 \%$ cassava flour and $30 \%$ cassava- pigeon pea flour. This finding will serve as an alternative for biscuit confectionary industries in Nigeria and other tropical countries in Africa that depends solely on imported and expensive wheat flour for processing. The nutritive value of pigeon pea in the biscuit could improve the nutritional status of children who consumes biscuit as snack food.

\section{References}

1. Ajani EN, Onwubuya EA (2013) Analysis of use of improved cassava production technologies among farmers in Anambra state, Nigeria. Wood Pecker Journal of Agricultural Research.

2. Onabolu AO, Oluwole OS, Bokanga M, Roshing H (2001) Ecology variation of intake of cassava food and dietary cyanide load in Nigerian communities. Public Health Nutrition 4: 871-876.
3. Nwosu JN, Ojukwu M, Ogueke CC, Ahaotu I, Owuamanam CJ (2013) The Antinutritional properties and ease of Dehulling on the proximate composition of Pigeon Pea (Cajanus cajan) as affected by malting. International Journal of Life Sciences 2: 60-67.

4. Ubbor SC, Akobundu ENT (2009) Quality characteristics of cookies from composite flours of watermelon seed, cassava and wheat. Pakistan Journal of Nutrition 8: 1097-1102.

5. Eneche EH (1999) Biscuit making potential of millet/pigeon pea flour blends. Plant Foods for Human Nutrition 54: 21-27.

6. AOAC (1990) Official method of Analysis $15^{\text {th }}$ Edition Association of Official Analytical Chemists, Washington D.C

7. Bradbury MG, Egan SV, Bradbury JH (1999) Determination of all forms of cyanogens in cassava and cassava products using picrate paper kits. Journal Sci Food Agric 79: 593-601.

8. Ashaye OA, Obatolu VA, Amusa NA, Fasoyiro SB, Ayoola OT, et al. (2007) Tips and Strategies for Profitable Cassava Production, Processing and Export.

9. Onwuka GI (2006) Soaking, boiling and antinutritional factors in Pigeon Peas. (Cajanus Cajan) and Cowpeas (Vigna. Unguiculata). Journal of Food Processing and Preservation 30: 616-630.

10. Neha M, Ramesh C (2012) Development of functional biscuit from soyflour and rice bran. International Journal of Agricultureal and Food Science 2: 14-20.

11. Oluwamukemi MO, Oluwalana TB, Akinbowale OF (2011) Physicochemical and sensory properties of wheat-cassava composite biscuit enriched with soy flour 5: 50-56.

12. Ogunjobi MA, Ogunwolu SO (2010) Physicochemical and sensory properties of cassava flour biscuits supplemented with cashew Apple powder. Jouirnal of Food Technology 8: 24-29.

13. Camire ME, Douggherty MP, Briggs JL (2007) Functionality of fruit powders in extruded corn breakfast cereals. Food Chemistry 101: 765-770.

14. Taiwo KA (2006) Utilization potentials of Cassava in Nigeria: The Domestic and Industrial Products. Food Reviews International 22: 29-42. 